\title{
Demand for Indonesia's Coconut Crude Oil in the Netherlands: Application of LA/AIDS Model
}

\author{
Imanuel do Rosário Ximenes ${ }^{1 *}$, Rita Nurmalina², Amzul Rifin² \\ ${ }^{1}$ Graduate School of Agribusiness, Postgraduate School, Institut Pertanian Bogor, Bogor, Indonesia \\ ${ }^{2}$ Departement of Agribusiness, Faculty of Economics and Management, Institut Pertanian Bogor, Dramaga, Indonesia \\ Email: *coutchay@gmail.com
}

How to cite this paper: Ximenes, I. do R., Nurmalina, R., \& Rifin, A. (2022). Demand for Indonesia's Coconut Crude Oil in the Netherlands: Application of LA/AIDS Model. Open Journal of Business and Management, 10, 144-154.

https://doi.org/10.4236/ojbm.2022.101009

Received: November 12, 2021

Accepted: January 3, 2022

Published: January 6, 2022

Copyright (C) 2022 by author(s) and Scientific Research Publishing Inc. This work is licensed under the Creative Commons Attribution International License (CC BY 4.0).

http://creativecommons.org/licenses/by/4.0/

\begin{abstract}
Besides the Philippines, Indonesia is the second-largest coconut crude oil exporter country in the Netherlands. The level of competition for Indonesia's coconut crude oil (CCO) is necessary to estimate in the main market. The primary aim of this study was to analyze the level of competition for Indonesia's coconut crude oil in the Netherlands, using a linear approximate AIDS model. The data used monthly time series on import values and quantities from 2004 to 2019 by the Netherlands. The results indicate that Indonesia's position in the Netherlands was inferior compared to the Philippines. The own-price elasticity of Indonesia's coconut crude oil was non-sensitive to the price change. Moreover, Indonesia and the Philippines were competing with each other. Thus, increasing the coconut crude oil export and improving quality size is one of the alternative strategies to catch up with the competition in the Netherlands.
\end{abstract}

\section{Keywords}

Coconut Crude Oil, LA/AIDS, Competition, Indonesia

\section{Introduction}

Vegetable oils are an indispensable commodity in the world food oil trade. Demand for vegetable oils in the world continued to rise gradually. Recently, coconut crude oil was one of the vegetable oils that dominated the world's food oil based on health issues. The product is beneficial for human health that contains active ingredients such as tocopherols, phytosterols, and polyphenols (Carandang, 2008). This product is generally used as industrial raw material (Anajohn, 2018; Burnett et al., 2011). Coconut crude oil also can be used as a raw material for the food and pharmaceutical industry. 
As the largest coconut producer, Indonesia has an opportunity to increase its export in the world market, including the Netherlands. In recent years, Indonesia has become the largest coconut-producing country globally, with an average of 18.3 million tons per year (FAOSTAT, 2021). However, Indonesia requires obtaining a policy that can benefit both coconut farmers and industries in trade flows. The low income of coconut farmers and the coconut industry is caused by the low supply of industrial raw materials, monoculture planting systems, inefficient supply chains, price fluctuations, limited product diversification, and low quality (Alouw \& Wulandari, 2020).

Coconut crude oil export has oscillated in the world market. The Philippines and Indonesia contributed $54.40 \%$ and $33.60 \%$, respectively. This means that both countries can export to the world market by $88 \%$. In 2010, the Philippines achieved the highest export level in the world at 1.05 million tons. In comparison, Indonesia declined in the export quantity of 0.23 million tons in 2017. This condition became a strategic issue for Indonesia in the world's coconut crude oil trade (Figure 1).

On the importer side, the Netherlands is the world's largest coconut crude oil importer country during the period. As coconut crude oil has various health benefits, there has been an exponential demand in the Netherlands. Nevertheless, there was a dip of 1.67 thousand tons in 2009, and even below the Unite States of America and Germany. The prices for coconut oil tended to be high, and the Netherlands substituted palm kernel oil (CBI, 2016). The price of coconut oil is higher than other vegetable oils in the world, with an average of US $\$ 1056.65$ per ton. Meanwhile, the average price for other vegetable oil is US\$742.33 for palm oil, US\$943.47 for rapeseed oil, and US\$888.73 for soybean oil (Index Mundi, 2021) (Figure 2).

The world's demand for vegetable oil went up regularly by 315.2 million tons in 2030 as long as the growth of the world population and the need for energy sources from fossil to vegetable oil (Rifai et al., 2014). Coconut crude oil mainly

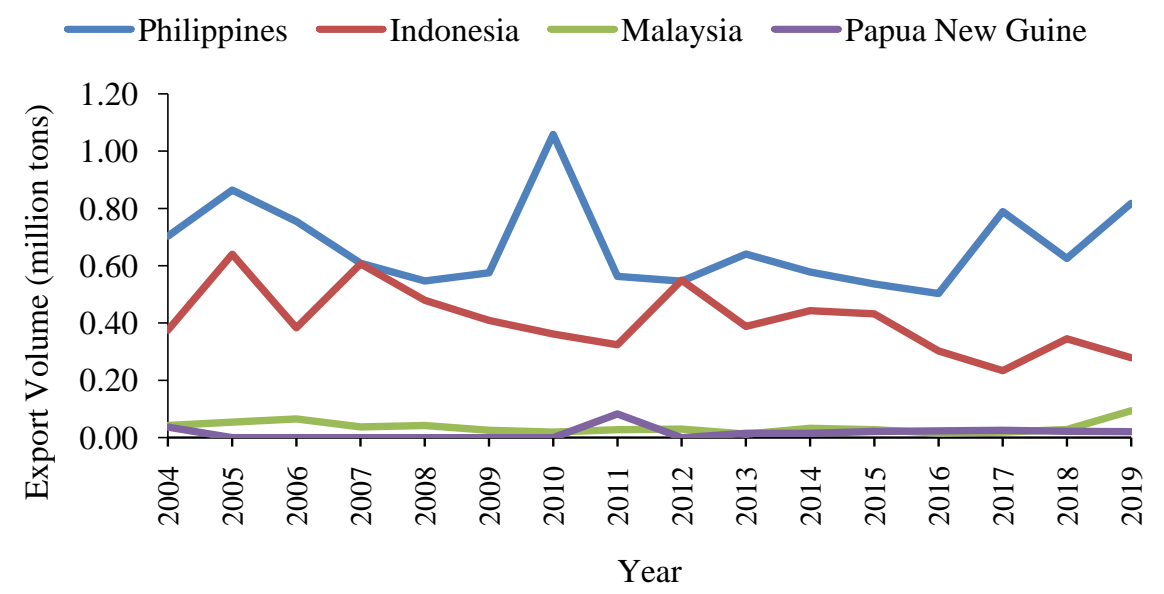

Figure 1. Largest coconut crude oil export in the world, 2004-2019. Source: Trade Map, 2021. 


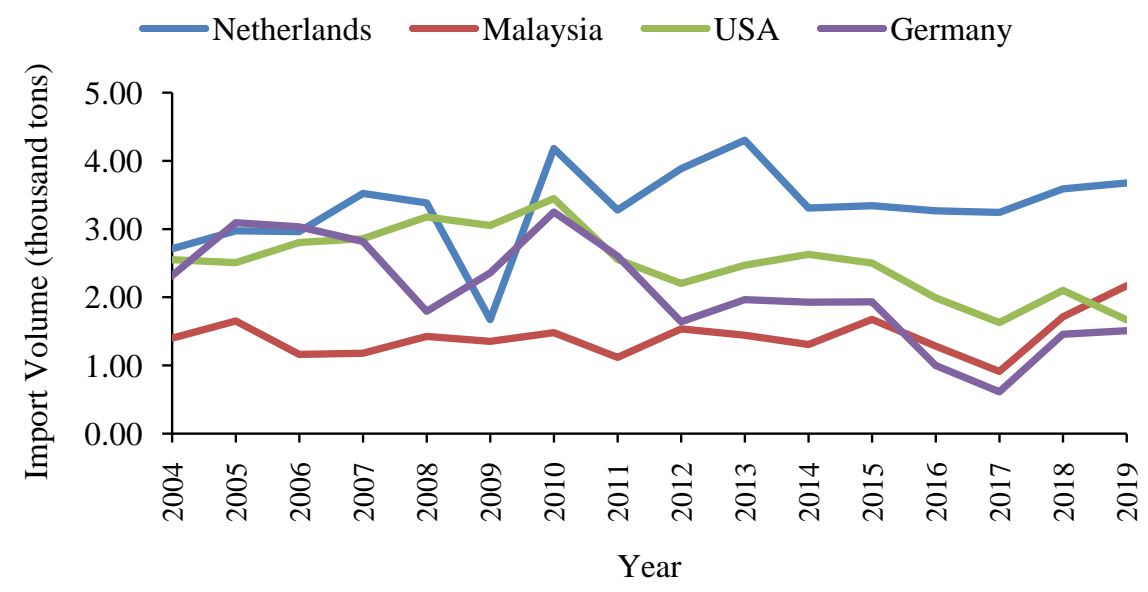

Figure 2. Largest coconut crude oil import in the world, 2004-2019. Source: Trade Map, 2021.

contributes to this demand. Consumers in the Netherlands preferred coconut crude oil because of health and environmental issues. The Netherlands became an entrepot trade in European countries. The country imported the coconut crude oil and then exported it to another European country. From 2015 to 2019, the Netherlands has exported the product to other European countries by $97.30 \%$. This study aimed to analyze the competition level for Indonesia's coconut crude oil in the Netherlands. The estimated parameters will formulate a strategy for Indonesia's market position in the future.

This article is organized as follows: provide the background information, the following section mentions the result of the previous research related to the topic, followed by the overview of the coconut crude oil import in the Netherlands, and employs the empirical model that used for the data analysis. Subsequently, describe and interpret the results and discussion. Finally, summarize the main findings within the broader context in conclusion and formulate the strategies.

\section{Literature Review}

An Almost Ideal Demand System (AIDS) model is often used in various studies in demand systems. Originally, Deaton and Muellbauer developed the AIDS Model in 1980. This model can display consumer behavior at the macro or micro level in the aggregate through its flexible functional structure and is relatively easy to estimate and interpret (Alston \& Chalfant, 1993). Several studies applied the AIDS model, including food demand analysis (e.g., Selvanathan et al., 2015; Hayat et al., 2016; Essaten et al., 2018; Zhou, 2015; Elzaki et al., 2021; Onyeneke et al., 2020; Nikmatul et al., 2020), and trade flows (Muhammad et al., 2013; Mekonnen et al., 2011; Boonsaeng et al., 2008; Rifin, 2013; Widarjono, 2018). The AIDS model also had many modifications in general, including nonlinear and linear AIDS, quadratic AIDS (QUAIDS), inverse AIDS, and others. Deaton and Muellbauer (1980) modified the AIDS model to linearize approximate AIDS or LA/AIDS in the demand system. 
A few studies are analyzing Indonesia's coconut crude oil trade in the world market. Sukmaya (2017) calculated the demand for Indonesia's coconut crude oil imports in the international market by using the AIDS model. The expenditure elasticity of Indonesia is higher than the Philippines in the international market. The Hicksian own-price elasticity for Indonesia, the Philippines, Malaysia, the USA, and the Netherlands is a negative sign. Malaysia, the Netherlands, and the Philippines are sensitive to its price. The relationship between Indonesia and Malaysia and the USA is a substitute for both Marshallian and Hicksian elasticity. Moreover, the relationship between Indonesia and Netherland is a complement either in Marshallian and Hicksian price elasticity. Thus, the share of Indonesian exports will decrease if the export price in the Netherlands increases. Meanwhile, the relationship between Indonesia and the Philippines is a substitute in Hicksian elasticity and complement in Marshallian elasticity. The relationship between Indonesia and the ROW is a complement in Marshallian and Hicksian price elasticity.

Furthermore, Tanago and Kaluge (2019) calculated factors that influence export quantity for Indonesia's and the Philippines coconut oil by using multiple linear regression. The results indicated that the price (of coconut oil, crude palm oil, virgin olive oil) and GDP have no significant impact on the Philippines export quantity. In contrast, Indonesia's coconut oil export quantity is significantly influenced by GDP. Yulhar and Darwanto (2019) investigated Indonesia’s coconut crude oil export competitiveness in destination countries. The results showed that Indonesia had competitiveness in the USA, the Netherlands, Malaysia, China, and Singapore. The Revealed Comparative Advantage (RCA) index average in each country demonstrated that Indonesia had a decisive comparative advantage. Export Product Dynamic (EPD) analysis also showed that Indonesia was in the rising star position in the Netherlands, Malaysia, China, and Singapore.

\section{Indonesia's and the Philippine Market of CCO in the Netherlands}

The Netherlands is Indonesia's largest trading partner, investor, and export destination during the $20^{\text {th }}$ century. One of the superior products that both countries obtain in trade is coconut oil. As the potential for coconut crude oil increases in Europe, the Netherlands tends to increase its demand. Figure 3 displays the unit import value for Indonesian and the Philippines coconut crude oil import in the Netherlands from January 2004 to December 2019. The import value of Indonesia and the Philippines fluctuated from 2004 to 2019 in the Netherlands. The value of the Philippines is higher than Indonesia. The average import value of the Philippines in the Netherlands market was US\$22.16 million. In June 2018, the Philippines achieved the maximum import value of US\$69.18 million. Meanwhile, the average import value of Indonesia is US\$5.09 million. The highest import value of Indonesia carried out by the Netherlands occurred in May 2007 with US\$29.90 million. 


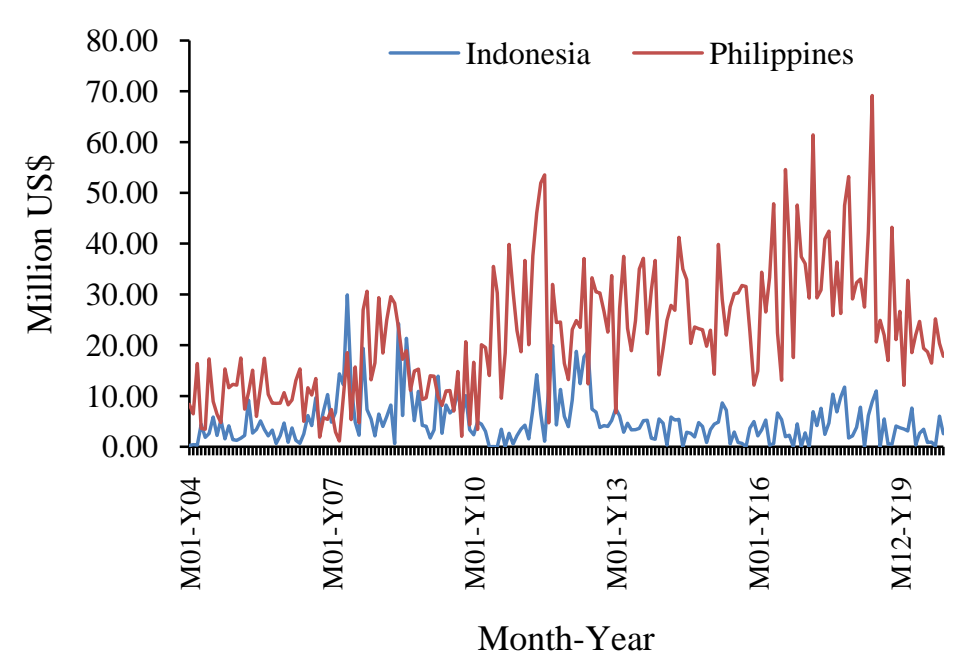

Figure 3. Unit import value for Indonesia's and the Philippines coconut crude oil in the Netherlands, 2004-2019. Source: Trade Map, 2021.

\section{The Empirical Model}

The AIDS model has become very powerful for analyzing trade flow between countries and regions. The model has also been extensively used due to its consistency and flexibility function (Chang \& Nguyen, 2002). Since its model can provide price and expenditure elasticity, we chose it as the empirical analysis for Indonesia's coconut crude oil import demand in the Netherlands. Deaton and Muelbauer (1980) developed the AIDS model for several advantages; it is able to offer an arbitrary first-order approximation to any demand system, the model can satisfy the axioms of choice exactly, it aggregates perfectly over consumers, it has a functional form which with household budget data, it is simple to estimate, it is able to avoid the non-linear system, and it is able to test the restrictions of homogeneity and symmetry. The modification of the AIDS model is a Linear Approximate AIDS or LA/AIDS regarding its non-linearity issue in the system. Deaton and Muellbauer (1980) developed the LA/AIDS by using the stone price index. Linear Approximate Almost Ideal Demand System model specifies as follows.

$$
w_{i}=\alpha_{i}+\sum_{j=1}^{n} \gamma_{i j} \ln p_{j}+\beta_{i} \ln \left(\frac{x}{p^{*}}\right)
$$

where $w_{i}=$ import share; $p=$ price (US $\$ /$ ton); $\alpha_{i}, \gamma_{i j}$ and $\beta_{i}=$ parameters; $x=$ total expenditure; and $p^{*}=$ stone price index. The stone price index $\left(p^{*}\right)$ in the LA/AIDS model is as follows:

$$
\ln p^{*}=\sum_{i=1}^{n} w_{i} \ln p_{i}
$$

However, the stone price index is not invariant to change in units of measurement (Moschini, 1995). He suggested employing the corrected stone price index from a log-linear version of the Laspeyres index as follow: 


$$
\ln P^{*}=\sum_{i=1}^{n} w_{i} \ln \frac{p_{i t}}{p_{t}^{0}}
$$

where $p_{t}^{0}$ denotes price on the base year.

The LA/AIDS model for coconut crude oil import in the Netherlands uses the corrected stone price index as follows.

$$
\begin{aligned}
& w_{\text {Ind }}=\alpha_{1}+\gamma_{1} \ln p_{\text {Ind }}+\gamma_{2} \ln p_{\text {Phil }}+\gamma_{3} \ln p_{\text {Row }}+\beta_{1} \ln \left(\frac{x}{p^{*}}\right) \\
& w_{\text {Phil }}=\alpha_{2}+\gamma_{4} \ln p_{\text {Ind }}+\gamma_{5} \ln p_{\text {Phil }}+\gamma_{6} \ln p_{\text {Row }}+\beta_{2} \ln \left(\frac{x}{p^{*}}\right)
\end{aligned}
$$

where $w_{\text {Ind }}=$ import share of Indonesia; $w_{\text {Phil }}=$ import share of the Philippines; $\alpha_{1}, \alpha_{2}=$ intercept; $\gamma_{1}, \gamma_{2}, \ldots, \gamma_{6}=$ coefficient; $\beta_{1}, \beta_{2}=$ coefficient; $p_{\text {Ind }}=$ price of Indonesia; $p_{\text {Phil }}=$ price of the Philippines; $p_{\text {Row }}=$ price of Row; $x / p^{*}=$ Total import value that affected by the corrected stone price index.

There are three restrictions to be fulfilled with economic theory. The following properties need to be satisfied as follows:

$$
\begin{gathered}
\text { Addin up : } \sum_{i=1}^{n} \alpha_{1}=1, \sum_{i=1}^{n} \gamma_{i j}=0, \sum_{i=1}^{n} \beta_{i}=0 \\
\text { Homogeneity }: \sum_{i=1}^{n} \gamma_{i j}=0 \\
\text { Symmetry }: \gamma_{i j}=\gamma_{j i}
\end{gathered}
$$

Estimating Equations (4) and (5) use the Seemingly Unrelated Regression (SUR) in the statistical software STATA 15. The parameter estimates of LA/AIDS is used to compute the price and expenditure elasticities. Following Rifin (2013), this study used the price elasticity and expenditure elasticity estimation. Price elasticity is calculated by uncompensated (Marshallian) representing price and income effect, and Hicksian (compensated) price elasticity, which contains only price effects. Both price and expenditure elasticity are as follows:

$$
\begin{gathered}
e_{i j}=-\delta_{i j}+\frac{\gamma_{i j}}{w_{i}}-\beta_{i}\left(\frac{w_{j}}{w_{i}}\right) \\
e_{i j}^{*}=-\delta_{i j}+\frac{\gamma_{i j}}{w_{i}}+w_{j} \\
\eta_{i}=1+\frac{\beta_{i}}{w_{i}}
\end{gathered}
$$

where $\delta_{i j}$ is the Kronecker delta ( 1 for $i=j$ and 0 otherwise).

This study applied 16 years of monthly time series data from 2004 to 2019 on values and quantities of coconut crude oil import by the Netherlands. The data in this study provides 192 observations. The data was collected from the ITC-Trade Map database by adopting a six-digit HS code (151311). The unit import values come from the total import value divided by the total import volume. 
As the largest producer country, Indonesia has to be concerned about the demand in the primary market. Indeed, most of Indonesia's coconut crude oil supplies are in Europe, especially in the Netherlands. Import share is presented in Table 1 (as shown in Column Mean). Coconut crude oil from the rest of the world is the most expensive (US\$700/ton), the Philippines is the cheapest one (US\$541/ton), and the average price from Indonesia is US $\$ 551 /$ ton.

\section{Results and Discussions}

The Netherlands is the largest importing country globally, with an average of 333.213-tonnes per year (Trade Map, 2021). So far, $93.87 \%$ of the coconut crude oil imported by the Netherlands comes from the Philippines and Indonesia. The average share of coconut crude oil imports presents that the Philippines occupies the first position of $74.15 \%$, while Indonesia only has an average share of $19.72 \%$ (Table 1).

\section{Elasticity Estimates}

Compensated (Hicksian), uncompensated (Marshallian), and expenditure elasticities are estimated by using the coefficients in the AIDS equation (Table 2). File attached is more detailed. Price and expenditure elasticity is estimated to see the competition between Indonesia and the Philippines in the Netherlands. Expenditure elasticity is the percentage change in demand for coconut crude oil import by the Netherlands. The expenditure elasticity value of Indonesia's coconut crude oil is a positive sign, implying that Indonesia's coconut crude oil is a normal good. The value of expenditure elasticity from Indonesia is 0.8967 , indicating that If the Netherlands increases 1 percent on coconut crude oil imports, it will increase the import demand from Indonesia by 0.8967 percent, ceteris paribus. The share of coconut crude oil import from the Philippines will be larger and more profitable than Indonesia because the Philippines expenditure elasticity is higher (Table 3 ).

The price elasticity of both Marshallian and Hicksian elasticity is a negative sign in the Netherlands, implying that when the price of coconut crude oil increases by 1 percent, the demand from the Netherlands will decrease, ceteris paribus. Indonesia's own-price elasticity value is inelastic because the absolute value

Table 1. Summary for the LA/AIDS variables in the Netherlands.

\begin{tabular}{lccccc}
\hline \multicolumn{1}{c}{ Variables } & Obs. & Mean & Std. Dev. & Min. & Max. \\
\hline Import share of Indonesia (\%) & 192 & 19.72 & 16.60 & 0.00 & 90.51 \\
Import share of the Philippines (\%) & 192 & 74.15 & 18.51 & 7.37 & 98.83 \\
Price of Indonesia (\$/Ton) & 192 & 551.47 & 517.24 & 0.00 & 2293.14 \\
Price of the Philippines (\$/Ton) & 192 & 541.41 & 499.32 & 0.71 & 2092.15 \\
Price of Row (\$/Ton) & 192 & 700.19 & 917.69 & 1.13 & 9666.67 \\
Total Import (\$) & 192 & 28,742 & 13,393 & 5,707 & 78,945 \\
\hline
\end{tabular}


Table 2. Result of LA/AIDS in the Netherlands.

\begin{tabular}{ccc}
\hline \multirow{2}{*}{ Variables } & \multicolumn{2}{c}{ Netherlands } \\
\cline { 2 - 3 } & $W_{\text {Ind }}$ & $W_{\text {Phil }}$ \\
\hline$P_{\text {Ind }}$ & 0.0400 & -0.0367 \\
$P_{P h i}$ & -0.0367 & -0.0121 \\
$P_{\text {Row }}$ & -0.0033 & 0.0488 \\
$X$ & -0.0203 & 0.0217 \\
$R^{2}$ & 0.2012 & 0.2863 \\
\hline
\end{tabular}

Table 3. Demand elasticity for Indonesia's coconut crude oil in the Netherlands.

\begin{tabular}{lccc}
\hline \multicolumn{1}{c}{ Elasticity } & $P_{\text {Ind }}$ & $P_{\text {Phi }}$ & $P_{\text {Row }}$ \\
\hline Price & & & \\
\hline $\begin{array}{lll}\text { Marshallian (Uncompensated) } \\
P_{\text {Ind }}\end{array}$ & -0.8164 & -0.2637 & -0.0232 \\
$\quad P_{\text {Phi }}$ & -0.0437 & -0.9946 & 0.0676 \\
Hicksian (Compensated) & & & \\
$\quad P_{\text {Ind }}$ & -0.5998 & 0.5551 & 0.0447 \\
$\quad P_{\text {Phi }}$ & 0.1469 & -0.2742 & 0.1273 \\
\hline Expenditure & & & \\
\hline Indonesia & & 0.8967 & \\
Philippines & & 1.0293 & \\
\hline
\end{tabular}

is less than 1 , which means not sensitive to price changes. In contrast, the own-price elasticity of the Philippines is close to unitary. Hicksian cross-price elasticity was estimated to discover how competitive position for Indonesia's coconut crude oil in the Netherlands market. The estimated elasticity of cross-price elasticity reveals that the relationship between Indonesia and the Philippines is a substitute. Although the value is not elastic $(<1)$, they are competing in the Netherlands. The values for Indonesia and the Philippines cross-price elasticity are 0.5551 , implying that when the price of Philippines coconut crude oil increases by 1 percent, it will increase the demand for Indonesia coconut crude oil by 0.5551 percent. Indonesia is likewise competing with the ROW (rest of the world). The findings are not in line with the previous findings. We speculate that using the proposed model (LA/AIDS) with the original AIDS model obtain different results. The different findings are expenditure elasticity and the relationship between Indonesia and the rest of the world. An apparent limitation of the empirical analysis here was not estimating the consistency of time series data.

\section{Conclusion}

Coconut crude oil demand in the Netherlands increased due to health and envi- 
ronmental issues. It is essential to see how far Indonesia's competition on coconut crude oil import is in the Netherlands. Indonesia and the Philippines are the largest coconut crude oil exporters in the Netherlands market. The Philippines occupies the first position at $74.15 \%$; meanwhile, Indonesia only has an import share of $19.72 \%$. Expenditure elasticity of Indonesia's coconut crude oil import is a normal good. The price of Indonesia's coconut crude oil import is flexible to its price in the Netherlands. The relationship between Indonesia and the Philippines is a substitute rather than complement each other. Therefore, this study encourages Indonesia to increase the export of coconut crude oil to the Netherlands when the Philippines increases the import price. In addition, Indonesia needs to improve the quality size as a prior strategy for pursuing a competitive position in the Netherlands. For further research, analysis of influencing factors will extend a deeper view of import demand for Indonesia's coconut crude oil in the Netherlands.

\section{Conflicts of Interest}

The authors declare no conflict of interest regarding the publication of this paper.

\section{References}

Alouw, J. C., \& Wulandari, S. (2020). Present Status and Outlook of Coconut Development in Indonesia. IOP Conference Series: Earth and Environmental Science, 418, Article ID: 012035. https://doi.org/10.1088/1755-1315/418/1/012035

Alston, J. M., \& Chalfant, J. A. (1993). The Silence of the Lambdas: A Test of the Almost Ideal and Rotterdam Models. American Journal of Agricultural Economics, 75, 304-313. https://doi.org/10.2307/1242914

Anajohn, J. (2018). Developments in World Trade with Coconut Oil. Thesis, Institut Pertanian Bogor.

Boonsaeng, T., Fletcher, S. M., \& Carpio, C. E. (2008). European Union Import Demand for In-Shell Peanuts. Journal of Agricultural and Applied Economics, 40, 941-951. https://doi.org/10.1017/S1074070800002431

Burnett, C. L., Bergfeld, W. F., Belsito, D. V., Klaassen, C. D., Marks Jr., J. G., Shank, R. C., Slaga, T. J., Snyder, P. W., \& Andersen, F. A. (2011). Final Report on the Safety Assessment of Cocos Nucifera (Coconut) Oil and Related Ingredients. International Journal of Toxicology, 30, 5-16. https://doi.org/10.1177/1091581811400636

Carandang, E. V. (2008). Health Benefits of Virgin Coconut Oil. Indian Coconut Journal, $38,8-15$.

CBI (2016). CBI Product Factsheet: Coconut Oil in the Netherlands. CBI Market Information Database. CBI Ministry of Foreign Affairs of the Netherlands.

Chang, H. S., \& Nguyen, C. (2002). Elasticity of Demand for Australian Cotton in Japan. The Australian Journal of Agriculture and Resource Economics, 46, 99-113. https://doi.org/10.1111/1467-8489.00169

Deaton, A., \& Muellbauer, J. (1980). An Almost Ideal Demand System. The American Economic Review, 70, 312-326.

Elzaki, R., Sisman, M. Y., \& Al-Mahish, M. (2021). Rural Sudanese Household Food 
Consumption Patterns. Journal of the Saudi Society of Agricultural Sciences, 20, 58-65. https://doi.org/10.1016/j.jssas.2020.11.004

Essaten, S., Mekki, A. A. EI., \& Serghini, M. (2018). Econometric Analysis of Cereal Demand in Morocco Using the Almost Ideal Demand System Model. International Journal of Food and Agricultural Economics, 6, 63-71.

FAOSTAT (2021). Coconut Production Quantity. http://www.fao.org/faostat/en/\#compare

Hayat, N., Hussain, A., \& Yousaf, H. (2016). Food Demand in Pakistan: Analysis and Projections. South Asia Economic Journal, 17, 94-113. https://doi.org/10.1177/1391561415621826

Index Mundi (2021). Vegetable Oils and Protein Meal. https://www.indexmundi.com

Mekonnen, D. K., Fonsah, E. G., \& Borgotti, B. (2011). US Import Demand for Apple: Source Differentiated Almost Ideal Demand System Approach. International Journal of Trade and Global Markets, 4, 372-382. https://doi.org/10.1504/IJTGM.2011.042862

Moschini, G. (1995). Units of Measurement and the Stone Index in Demand System Estimation. American Journal of Agricultural Economics, 77, 63-68. https://doi.org/10.2307/1243889

Muhammad, A., Leister, A. M., McPhail, L., \& Chen, W. (2013). The Evolution of Foreign Wine Demand in China. Australian Journal of Agricultural and Resource Economics, 58, 392-408. https://doi.org/10.1111/1467-8489.12029

Nikmatul, K., Ratya, A., Nuhfil, H., \& Wahib, M. A. (2020). The Analysis Demand for Animal Source Food in Indonesia: Using Quadratic Almost Ideal Demand System. Verslas: Teorija ir praktika / Business: Theory and Practice, 21, 427-439. https://doi.org/10.3846/btp.2020.10563

Onyeneke, R. U., Emenekwe, C. C., Amadi, M. U., Munonye, J. O., Njoku, C. L., \& Izuogua, C. U. (2020). Demand Analysis of Rice in Nigeria: Application of Quadratic Almost Ideal Demand System Model. Asian Journal of Agriculture and Rural Development, 10, 364-378. https://doi.org/10.18488/journal.1005/2020.10.1/1005.1.364.378

Rifai, N., Syaukat, Y., Siregar, H., \& Sa'id, E. G. (2014). Dampak Pengembangan Produk Turunan Minyak Sawit terhadap Peningkatan Ekspor Produk Minyak Sawit ke Pasar Amerika Serikat (Impact of the Palm Oil Derivative Products Development on the Increase of Palm Oil Products Export to the USA Market). Jurnal Agro Ekonomi, 32, 107-125. https://doi.org/10.21082/jae.v32n2.2014.107-125

Rifin, A. (2013). Analysis of Indonesia's Market Position in Palm Oil Market in China and India. Journal of Food Products Marketing, 19, 299-310. https://doi.org/10.1080/10454446.2013.726950

Selvanathan, S., Selvanathan, E. A., Albalawi, S., \& Hossain, M. (2015). Meat and Fish Consumption Patterns in Saudi Arabia. Applied Economics, 48, 446-460. https://doi.org/10.1080/00036846.2015.1083081

Sukmaya, S. G. (2017). Analisis Permintaan Minyak Kelapa (Coconut Crude Oil) Indo-nesia di Pasar Internasional (Analysis of Indonesia's Coconut Crude Oil Import Demand in the International Market). Journal of Agribusiness and Rural Development Research, 3, 1-8.. https://doi.org/10.18196/agr.3138

Tanago, R., \& Kaluge, D. (2019). What Factors Influencing Export Quantity for Indonesian and Philippine Coconut Oil. Jurnal Ekonomi dan Studi Pembangunan, 11, 186-192. https://doi.org/10.17977/um002v11i22019p186

Trade Map (2021). Trade Statistics for International Business Development. 
https://www.trademap.org

Widarjono, A. (2018). Analysis of Rice Imports in Indonesia: AIDS Approach. Journal of Economics, Business, and Accountancy Ventura, 21, 259-268. https://doi.org/10.14414/jebav.v21i2.1212

Yulhar, T. F. M., \& Darwanto, D. H. (2019). Competitiveness of Indonesian Crude Coconut Oil Export in Destination Countries. Agro Ekonomi, 30, 125-138.

https://doi.org/10.22146/ae.49014

Zhou, X. V. (2015). Using Almost Ideal Demand System to Analyze Demand for Shrimp in Us Food Market. International Journal of Food and Agricultural Economics, 3, 31-46. 